\title{
Islamic Radical Movements and Antisemitism: Between Old and New
}

Islamist antisemitism in the past decades is exceptional in three major categories: It is more virulent than any other public expression of antisemitism in the world today. It is also the most openly genocidal form of existing antisemitism as the various Islamist spokesmen do not mince words about their aspirations regarding the intended fate of the Jews, which is total annihilation. Finally, it is probably the most widespread brand of antisemitism as it unifies numerous Islamists from a broad range of countries and movements, both Sunnis and Shi'is, mainstream and radicals alike.

\section{Modern Islamist Antisemitism and Traditional Anti-Judaism}

Antisemitism is inherent to Islamism as it is intertwined with two crucial conflicts that shape the ideology and psychology of all Islamist movements. The first is the clash with the cultural and political entity defined as the "West," the ultimate threatening other in modern Islamist worldview. The second concerns the fights that the Prophet Muhammad had waged against the Jewish tribes of Medina. The two confrontations do not only represent two extremely opposite time periods but two completely contradictory historical experiences of the Muslim community: predicament and distress vis-à-vis the West in the present period and the rise of Islam from a persecuted minority into a victorious community during the Prophet's lifetime.

Islamism is a modern reaction among Muslim communities to a deep sense of vulnerability and humiliation by modern Western-dominated global culture and the perceived threat it poses to Islamic identity. Judaism and Jews became popular targets of Islamist polemics or attacks, not because they may attract Muslims in the same manner as popular Western culture and ideologies. Rather, they are associated with the threat posed by the abhorred Western-dominated modernity and the dichotomy between the West and Islam. Since the basic idea of modern Islamism is to restore the power and glory of Islam, particularly as it had existed in the time of the Prophet Muhammad, it entails by definition a struggle against the enemies of Islam and of the Prophet, who are often lumped 
together. As the Jews of Medina were among the Prophet's major targets, they received special hostile attention in the Qur'an, much more than the Christians.

Zionism and the conflict with Israel are major factors in the emergence and evolution of Islamist antisemitism but not its cause, as they represent a powerful manifestation of the failures and predicaments of the Muslims in the modern period. Since Islamists tend to view or judge historical phenomena through the religious prism, they regard the struggle with Zionism as inherently religious, that is between Judaism and Islam. Thus they do not distinguish between Judaism and Zionism since they see the latter as the practical manifestation of the former and regard Jews everywhere as Israel's co-conspirators in a plot against Islam. In addition, since Islamists review the past and present as fully intertwined, they view the current struggle against Israel and Zionism as the continuation of the conflict between the Prophet and the Jews. Finally, like all other anti-Western, or Occidentalist, worldviews, it associates the Jews with Western modernity and views them as the carriers of the universalist virus, as the flag-bearers of capitalism and as the manifestation of "rootless cosmopolitanism."1 This truth is epitomized by the motto of the Houthi movement in Yemen: "Death to America, death to Israel, curse on the Jews, victory to Islam.” One should bear in mind that most Houthis had never seen a Jew in their life, as only a few hundred Jews remained there, and the country is situated some 2,220 km away from Israel and suffers from a bloody war among Muslims.

Like other fundamentalist movements, Islamism is a modern phenomenon, which combines pre-modern and modern characteristics. Modern Islamist antisemitism draws on the Qur'an and early Islamic traditions (Hadith). The Qur'an contains harsh passages against Jews in view of the conflict of the Prophet Muhammad with the Jewish tribes of Medina. But, as Martin Kramer has observed, pre-modern Islamic tradition did not hold up those Jews who supposedly practiced treachery against Muhammad as archetypes-as the embodiment of Jews in all times and places. This makes for a striking contrast with a certain Christian concept of the eternal Jew, who forever bears the mark of the betrayer of Jesus. The Qur'an also includes certain verses which attest to the Prophet's amicable relations with some Jews, and while religious supremacism always colored the traditional Islamic view of the Jews, it also colored the Islamic view of Christians and all other non-Muslims. ${ }^{2}$

1 I. Buruma, "The Origins of Occidentalism," The Chronicle of Higher Education, February 6, 2004, https://www.chronicle.com/article/The-Origins-of-Occidentalism/30792.

2 M. Kramer, "The Salience of Islamic Antisemitism," Institute of Jewish Affairs in London "Reports” series 2 (1995). 
During centuries of Muslim rule, up to the modern period, Jews never enjoyed equality with Muslims, as they were always subject to discriminatory laws, and there was always latent pressure to convert to Islam. Yet, Jews were entitled to the protection (dhimma) of Islam as "People of the Book" and enjoyed religious autonomy. Moreover, this anti-Judaism had never been as central and relentless as its Christian counterpart in the Middle Ages. Unlike Europe, where Jews were often singled out as a demonic and destructive force, Islamic doctrines did not attribute satanic powers to them. When Jews were discriminated against, it was mostly because they belonged to the subordinate non-Muslim class, rather than to the Jewish religion in particular. In addition, Muslim rulers did not always implement these discriminatory laws. Furthermore, during this period Jews were not perceived as a threat to Islam, unlike the Christians, who, as members of the opposing imperial forces, were seen as an imminent danger to Islamic dominance. Forced conversions were extremely rare, and there were far fewer persecutions under Islam than under Christian Europe. ${ }^{3}$

Unlike the past, the modern Islamists adopted a one-dimensional view of Jews drawn from a selective reading of scriptures instead of the more complex one in the past. Moreover, they have turned this Jew-hatred into a major theological construct of modern Islamist ideology. These developments reflected a shift from traditional anti-Judaism to modern antisemitism. Anti-Judaism refers to disdain for Jews and hostile attitudes toward Judaism and aims primarily at undermining Judaism's religious validity. Primarily, it blamed the Jews for rejecting the teaching of the Prophet Muhammad, for distorting and falsifying the true scriptures given to them by Moses, and for a host of immoral activities. The shift to antisemitism is evident in the growing demonization of the Jews as an active threat to Islam and the reliance on conspiracy theories, the use of terminology borrowed from European antisemitism, and the incorporation of genocidal themes. Here, it can be said that they are following a similar pattern of medieval Christianity which regards all Jews at all times as diabolic. The heavy political component of the new discourse, shown by linking the Jews to other modern political enemies of Islam similarly marks this transition. ${ }^{4}$

3 For analyses of Islamic attitudes toward the Jews, see B. Lewis, The Jews of Islam (Princeton: Princeton University Press, 1984); M. R. Cohen, Under Crescent and Cross: The Jews in the Middle Ages (Princeton: Princeton University Press, 1994); Y. Friedmann, Tolerance and Coercion in Islam: Interfaith Relations in the Muslim Tradition (New York: Cambridge University Press, 2003). For a critical view of Islamic attitudes, see B. Ye'or, The Dhimmi: Jews and Christians under Islam (Rutherford: Fairleigh Dickinson University Press, 1996).

4 For the difference between anti-Judaism and antisemitism, see G. I. Langmuir, Toward a Definition of Antisemitism (Berkeley: University of California Press, 1990), particularly 57-99; S. He- 
Like all fundamentalist movements, Islamism maintains an exclusivist claim to the truth. Therefore, they view other religions not simply as mistaken but at best as sinful and at worst as enemies of the one true God and message. Consequently, their attitude toward other religions is usually more exclusionary and hostile than among more mainstream religious trends. Fundamentalists view the world and history in dialectical terms as a permanent battle that takes place everywhere and all times, part of a great cosmic and spiritual confrontation between God's forces of good and Satan's forces of evil. ${ }^{5}$ If the world is a battlefield, and if personal or collective salvation or damnation is at stake, then the opponent or the infidel becomes ipso facto an enemy. Since fundamentalists believe that they are fighting for God and represent his true divine message, then their opponents become the enemies of God himself. Thus if the Islamists represent the "party of God" (Hizballah), then their enemies represent the "party of Satan" (hizb al-shaytan). ${ }^{6}$ Not surprisingly, most Islamists describe the Jews as the "enemies of God and humanity."

\section{The Uniqueness of Islamist Antisemitism}

Overall, among all modern fundamentalist movements, the Islamist response to the perceived external threat is much stronger and more virulent than other religions due to several reasons. The first is the wide gap between Muslim self-perception of the proper place of Islam in the world, expressed in the popular saying "al-Islam ya 'lu wala yu la alayhi" ("Islam should be on top, and nothing shall be above it") and the gloomy reality of the Islamic world's weakness and lagging behind most other regions in the world. Added to this is the gap between Islam's past glory and present-day weakness, particularly when this worldly power and glory served as a proof of Islam's right cause and theological superiority over other religions. These two gaps create a major cognitive dissonance among Islamists which threaten the foundation of Islamic theology. That is, the need to explain why is God's chosen religion is in such a bad state while the infidels

\footnotetext{
schel, "Historiography of Antisemitism Versus Anti-Judaism: A Response to Robert Morgan," Journal for the Study of the New Testament 33, no. 3 (2011): 257-79.

5 D. Zeidan, "The Islamic Fundamentalist View of Life as a Perennial Battle," Middle East Review of International Affairs 5, no. 4 (2001), https://myislam.dk/articles/en/zeidan\%20the-is lamic-fundamentalist-view-of-life-as-a-perennial-battle.php.

6 "Hiwar shamil ma‘a qiyadat Hamas," Filastin al-Muslima, April 1990.
} 
thrive. ${ }^{7}$ Article Nine of the Hamas Charter reflects this predicament vividly, when it states:

The Islamic Resistance Movement found itself at a time when Islam has disappeared from life. Thus rules shook, concepts were upset, values changed and evil people took control, oppression and darkness prevailed, cowards became like tigers: homelands were usurped, people were scattered and were caused to wander all over the world, the state of justice disappeared and the state of falsehood replaced it. Nothing remained in its right place. Thus, when Islam is absent from the arena, everything changes. ${ }^{8}$

Modern antisemitism in Muslim societies predated Zionism, but the most problematic and painful manifestations of the modern Muslim predicament are the emergence of Zionism, the establishment of the State of Israel in 1948, and Arab failure to defeat Israel ever since. The predicament is worsened by the belief that Jews carry God's wrath upon them (al-maghdub 'alayhim) because they had opposed the Prophet Muhammad and therefore they had been destined by God to be humiliated and dispersed among the nations. For centuries, Jews had been subordinated to Muslims and therefore the modern reality when they prevail over Muslims is particularly painful. Put differently, Israel is a daily reminder of Arab-Muslim failure in the modern era.

The second cause is the quest to return to the spirit and purity of the period of the Prophet Muhammad and for Sunnis also of the following three generations. All religions pay great attention to the past, but with Islamism this phenomenon is stronger, as both Sunnis and Shi'is view the first period of Islamic history as the major if not exclusive frame of reference for understanding and interpreting every historical phenomenon. Thus, for Islamists the conflict of the Prophet Muhammad with the Jews serves as the model that must be reenacted in order to restore history to its proper course. In addition, Muhammad's struggle serves as a source of inspiration and encouragement to his followers. He started his mission as a persecuted prophet but eventually defeated all his enemies and died as the ruler of Arabia. So today, the Muslims may be weaker than their enemies, but they too will be victorious at the end. ${ }^{9}$

Finally, the way the Prophet had dealt with the Jews after defeating them, from expulsion to wholesale massacre, serves as model to follow. The resort to the past intensified the literalist, uncritical, and totalistic reading of earlier Is-

7 B. Lewis, “The Roots of Muslim Rage,” The Atlantic Monthly (September 1990): 47-60.

8 The Covenant of the Islamic Resistance Movement, issued August 18, 1988, accessed February 21, 2020, https://avalon.law.yale.edu/20th_century/hamas.asp.

9 M. Litvak, "The Islamization of the Palestinian-Israeli conflict: The Case of Hamas," Middle Eastern Studies 34, no. 1 (1988): 157. 
lamic history. Such a reading led to the reopening, and the need to settle, various so-called "historical accounts," which Islam had with other religions and ideologies. This reading revived medieval polemics with non-Muslims, in this case the Jews, and highlighted the sins and evil they had committed against Muslims since the early days of Islam.

The return to the past revived the old image of Judaism as a harsh and excessively restrictive religion as opposed to the more tolerant and humane Islam. Traditional Islamic libel emanating from religious texts has typified the Jews as deceitful, bloodthirsty, hateful, money-loving and conniving, and accused them of falsifying historical and religious legacies, and of extreme hostility toward Muslims. ${ }^{10}$ A new theme which appeared in the modern age regarded the Jews as the cause of all the disasters that have befallen upon Arab and Muslim societies, as the driving force behind the present negative image of Islam in the world and of the wars launched by the West against it. ${ }^{11}$

The third cause, to use the words of the Syrian scholar Bassam Tibi, is the clash of universalism, since Islamism like Western civilization has a claim to universality as it explicitly seeks to extend its doctrine throughout the world and establish a new world order. For Islamic fundamentalists the West is evil incarnate because the expansion of the Western civilization has led to the denial of Islam's universalist claim. Moreover, this clash is a premeditated conspiracy devised by the Jews and crusaders against Islam. ${ }^{12}$ Ironically, the Islamists who oppose every aspect of Western culture have no problem whatsoever to borrow anti-Jewish myths and ideas from the same West.

Since Islamists tend to conflate the past and the present, the link between the past and present conflict with the Jews could not be more obvious. In the words of the prominent Saudi cleric Muhammad Saleh al-Munajid in May 2015:

The Jews today are the Jews of the past. This requires no proof ... and the Prophet Muhammad clarified that our war with them will continue until the end of time. ${ }^{13}$

Moreover, the Jews employ today the same tactics they had used against the Prophet such as unjustly shedding the blood of the Palestinians, just as they

10 H. Ben-Shammai, "Jew-hatred in the Islamic Tradition and the Koranic Exegesis," in Antisemitism Through the Ages, ed. Sh. Almog (Oxford: Pergamon, 1988), 161-69; G. Vajda, "Juifs et musulmans selon le hadith," Journal Asiatique 229 (1937): 57-127.

11 M. Kramer, “The Jihad Against the Jews," Commentary (October 1994): 38-42.

12 B. Tibi, The Challenge of Fundamentalism: Political Islam and the New World Disorder (Berkeley: University of California Press, 2002), 15.

13 MEMRI TV, Clip No. 5502, issued May 15, 2016, accessed August 7, 2020, https://www.memri. org/tv/saudi-cleric-muhammad-al-munajid-our-war-jews-plague-history-will-continue-end-time. 
had wrongfully shed the blood of the (biblical) prophets in the past. ${ }^{14}$ Another projection of the past to the present, which has become widespread in recent years is the depiction of the Jews as "Brothers of Apes and Pigs," based on a number of Qur'anic passages that state that some Jews were turned into apes and pigs by God, as a punishment for violating the Sabbath.

\section{The Jewish Threat to Islam}

These practices point to another characteristic of Islamist antisemitism that is psychological projection, where one side attributes to the "other" the harmful or problematic aspects of the self. In the Islamist case it transforms the Jews into active historical enemies who are motivated by hatred against Islam and the Muslims from the inception of Islam to the present. The Jews thus wage a war on Islam on a broad front, ranging from brutal murders through economic investments to cultural raids. According to this narrative, they play a key role in disseminating Islamophobia (Islam setizi) all over the world; as one writer explained, wherever there is injustice and oppression against Muslims, there are Jews standing behind it. ${ }^{15}$

Thus, the Shi'i Iranian Khomeini spoke of the Jewish enmity toward Islam from the time of the Prophet Muhammad but charged that in the modern period the Jews and Christians conspired against Islam in order to undermine its most important feature as a comprehensive and total system of law that governs society and state. In addition, the West, consisting of Jewish and Christian elements, resists the righteous cause of Islam to expand to the "four corners of the globe." "n the other end of the Islamist spectrum, Osama bin Laden founder

14 'A. al-'Aziz al-Rantisi, "Idha malaka al-sahayina quwa qatalu al-abriya li-tahqiq mukhattatihim al-khabith," in www.rantisi.net.

15 Kramer, "The Jihad Against the Jews"; Intelligence and Terrorism Information Center, January 25, 2010, http://www.terrorisminfo.org.il/malam_multimedia/English/eng_n/html/iran_ e048.htm [no longer available]; "Head of Iranian Think-Tank Advising Khamenei: The Jews Want Nuclear Bomb to Kill Muslims and Achieve World Domination,” MEMRI TV, Clip No. 4042, issued February 1, 2013, accessed August 7, 2020, https://www.memri.org/tv/head-iranian-think-tankadvising-khamenei-jews-want-nuclear-bomb-kill-muslims-and-achieve-world; "Sheikh of AlAzhar on Jewish-Muslim Animosity: The Jews Started It,” MEMRI TV, Clip No. 6019, issued May 4, 2017, accessed August 7, 2020, https://www.memri.org/tv/sheikh-al-azhar-jewish-mus lim-animosity-jews-started-it.

16 R. Khumayni, Al-hukuma al-islamiyya (Beirut: Dar al-Tali‘a, 1979), 7; R. Khomeini, Islam and Revolution: Writings and Declarations of Imam Khomeini, trans. and annot. H. Algar (Berkeley: Mizan, 1981), 27, 47. 
of al-Qaida spoke about the "Jews and Crusaders," who were waging a war against Islam. ${ }^{17}$

If the three causes are taken together, the Jews represent in many ways the most problematic, frustrating, and frightening aspects of Western-dominated modernity, that is so harmful to Islam. Thus, the Egyptian cleric 'Ala Sa'id in a TV sermon in January 2009 charged that the "Jews are behind the spreading of corruption and calamities worldwide," and attributed to them the major responsibility for "the bestial tendencies and the lust that are evident in the age of 'progress,' 'enlightenment,' and 'development”':

Who did this, publicized it, supported it, and was behind it? It was Freud the Jew. Homosexuality-may God forgive me-who spread it? It was Jean-Paul [Sartre] the Jew. Who spread atheism in the world? It was Karl Marx, who was also a Jew. ${ }^{18}$

The Saudi Islamist Nabil Hamad pursued the same line of associating the Jews with modernity, particularly the enlightenment, which undermined the foundations of the traditional religious societies of the past, when he explained that the "Zionist-Jewish den of iniquity began operating in the early 18th century. Who was Durkheim? Westerners view him as the father of modern sociology," he asked and responded,

Durkheim was a Jewish Zionist, who sowed destruction with the information he provided. Who was Darwin, who said that human beings descended from apes? He was one of the founders of Western thought. Who was Freud? He was the founder of modern psychology, and he emphasized sex as the primal impulse in human beings. Who was Nietzsche? He spoke of a blonde, blue-eyed Western "superman.” Who was Sartre? They were all Zionist Jews, except for Nietzsche, who was a Christian Zionist. ${ }^{19}$

Significantly, these statements are almost verbatim quotes from the writings from the early 1950s of Sayyid Qutb, one of founders of modern Islamism, thereby reflecting the continuity of themes of Islamist antisemitism. Needless to say, neither Darwin nor Sartre nor Nietzsche were Jews.

17 "Jihad Against Jews and Crusaders,” World Islamic Front Statement, https://fas.org/irp/ world/para/docs/980223-fatwa.htm.

18 MEMRI TV, Clip No. 2036, issued January 2, 2009, accessed August 7, 2020, http://www. memritv.org/clip_transcript/en/2036.htm.

19 MEMRI TV, Clip No. 4302, issued May 15, 2014, accessed August 7, 2020, https://www.memri. org/tv/saudi-scholar-mickey-mouse-sesame-street-characters-part-jewish-plot-destroy-human ity; S. Qutb, "Ma'arakatuna ma'a al-yahud," cited in S. G. Haim, "Sayyid Qutb," Asian and African Studies 16 (1982): 155-56. 
Similarly, reflecting a sense of weakness and vulnerability vis-à-vis modernity, the Saudi cleric Abdullah Ba Neema lamented that "the Jews conspire while we are in a slumber." He not only attributed many of the most advanced technological inventions associated with modernity to the Jews but described them as a devious weapon which appeals to what the Muslims crave in order to dominate them. Accordingly, "the Jews decided to use TV-that false idol-as a tool [in their schemes]," and he added, "WhatsApp is Jewish, Twitter is Jewish, Facebook is Jewish, Instagram is Jewish, and Snapshot is Jewish. All the social networks are Jewish. All our information is in their hands." The Jews have used all of these technologies in order to poison the hearts and minds of Muslims, and he concluded, "as a result of WhatsApp and Twitter, women's honor has been violated, men have divorced women, and men and women have committed adultery." 20

\section{The Prevalence of Conspiracy Theories}

Societies in crisis are often attracted to conspiracy theories which reduce complex and incomprehensible reality to seductive patterns of orderliness. They define dangers and bring a welcome rational order to unpleasant and erratic events. They relieve groups or individuals in "stress situations" from the pressure of reality, since they provide an explanation for their suffering. Even more comforting is that they exempt the aggrieved societies from responsibility for their predicament by blaming external forces for their perceived intolerable situation. The central role of the Jews in European conspiracy theories served as a source of inspiration and a "factual basis" for applying conspiracy theories to the Jews and Zionism in the context of the Middle East conflict. ${ }^{21}$

Conspiracy theories are rife in Middle Eastern societies because of the deep crisis they suffer from, their difficulty in coping with the challenges of the modern age. Another possible reason for their popularity is the historical legacy of political domination by military elites, which promoted a culture that discourages political activism and the assumption of personal and collective responsibility

20 MEMRI TV, Clip No. 4898, issued May 3, 2015, accessed August 7, 2020, https://www.memri. org/tv/saudi-islamist-preacher-jews-poison-muslims-hearts-and-minds-whatsapp-twitter-andfacebook.

21 For an analysis of conspiracy theories as a theme of social psychology, see C. F. Graumann and S. Moscovici, eds. Changing Conceptions of Conspiracy (London: Springer, 1987). On the role attributed to Jews, see H. Zukier, "The Conspiratorial Imperative: Medieval Jewry in Western Europe," in Changing Conceptions of Conspiracy, 87-105. 
for the social and economic ills of society and blamed them on others. Not surprisingly the most notorious modern conspiracy theory in modern history, The Protocols of the Elders of Zion, has been extremely popular in the Muslim world where 59 editions have been published since the 1920s and are extensively quoted by all Islamist leaders and movements.

Another manifestation of widespread resort to conspiracy theories and the tendency of Arabs and Islamists to absolve their societies of responsibility to their problems has been the attribution of Jewish origins to unpopular political leaders. Islamic tradition in the past traced most religious heresies to Jewish originators, the most famous being 'Abdullah ibn Saba, who was supposedly responsible for instigating the "Sunni-Shi'i split." 22 Modern Islamists go much further. Mustafa Kemal Ataturk had long been held as a Jew thus providing an explanation for the 1924 abolition of the Caliphate. But once the Arab upheaval began in 2011, the conspiracy theories went to greater extremes than ever before. Each camp, whether revolutionary or old regime, has not only accused the other of conspiring with Zionism and the Jews but has actually exposed them as "being Jewish." Thus, a host of leaders from Gamal Abdel Nasser and Hosni Mubarak of Egypt, Muammar Gaddafi of Libya, Bashar al-Assad of Syria, the Saudi royal family and even Islamist figures such as Hasan al-Banna, founder of the Muslim Brotherhood and Muhammad b. 'Abd al-Wahhab, founder of the puritanical eighteenth-century Wahhabiyya sect, are awarded Jewish ancestry. ${ }^{23}$

The scope of this practice demonstrates two phenomena: the first, which Esther Webman has written about, is the evolution of the Jew into a metaphor for evil. It serves to define non-Jewish adversaries by Judaizing them and attributing to them certain supposed features of Jews, while denouncing them for their actions. $^{24}$

The other point is that such widespread charges are in fact an admission of failure, helplessness, and incompetence of Muslim-Arab societies, if their enemies manage to manipulate and dominate them to such an extent. At the same time, such perceptions absolve the Muslims of any responsibility to their failures by attributing them to foreign machinations. In other words, the Islamist

22 S. Wasserstrom, Between Muslim and Jew: The Problem of Symbiosis under Early Islam (Princeton: Princeton University Press, 2014), 157.

23 http://www.shabkh.com/view1thread.php?id=5188 [no longer available]; http://www.ejaaba.com/208390; https://www.ejaaba.com/214359; S. Tadros, "The Sources of Egyptian Anti-Semitism,” American Interest, April 21, 2014, https://www.the-american-interest.com/2014/04/21/thesources-of-egyptian-anti-semitism/.

24 E. Webman, "The 'Jew' as a Metaphor for Evil in Arab Public Discourse," The Journal of the Middle East and Africa 6, nos. 3-4 (2015): 275-92. 
case, like all other types of antisemitism, prevents Muslim society from confronting its own weaknesses and failings by blaming outsiders and preclude the possibility of actually addressing and solving these problems. Jews are the targets of this hatred, but Muslims pay the cost of its negative effect on their society.

The inclination to adopt conspiracy theories produces internal contradictions, which are typical of many antisemitic movements. Thus, Islamists deny Jewish nationalism and they describe the Jews as an amalgam of totally disparate groups with nothing in common among them except their religion. Concurrently, they insist that all Jews throughout the world share the same eternal characteristics and aspirations, and they all strived to attain their goals throughout the centuries under a unified leadership. Similarly, they often deny the Holocaust but justify Hitler's extermination of the Jews as the proper punishment for their sins and crimes. ${ }^{25}$

\section{Genocide as Divine Punishment}

An important theme, which demonstrates the evolution from traditional anti-Judaism to modern conspiratorial antisemitism is the issue of Jewish corruption. The Qur'an and early Islamic traditions charged that the Jews "strive throughout the land [causing] corruption" (5:64) and described it as a major reason for their punishment by God. Modern Islamist antisemitism expands this charge to accuse the Jews of exerting concerted and widespread efforts to corrupt all nonJewish societies. The ultimate proof of their activities is The Protocols of the Elders of Zion, which Islamists quote widely. Specifically, the Jews are behind the major corrupt manifestations of modern Western societies, especially the spread of pornography. ${ }^{26}$ The obvious conclusion is that the "Jews are the true source of

25 For such phenomena, see E. Webman, "The Challenge of Assessing Arab/Islamic Antisemitism,” Middle Eastern Studies 46, no. 5 (2010): 683; M. Litvak and E. Webman, From Empathy to Denial: Arab Responses to the Holocaust (New York: Columbia University Press, 2009), 381. 26 For a few examples among many, see Muhammad Saleh al-Munajid, "Ifsad al-yahud fi alard," https://almunajjid.com/speeches/lessons/383; "Egyptian Cleric Abd Al-Fattah Abu Zayd: The Jews Use Internet Porn To Corrupt The Muslims-As Per 'The Protocols', MEMRI, Special Dispatch No. 5073, issued December 1, 2012, accessed August 7, 2020, https://www.memri.org/ reports/egyptian-cleric-abd-al-fattah-abu-zayd-jews-use-internet-porn-corrupt-muslims- $\% \mathrm{E} 2 \%$ 80\%93-protocols; "Al-Jazeera's Midan Voice Internet Channel: Jews Created And Control The Porn Industry In Order To Pollute American And Christian Values,” MEMRI, Special Dispatch No. 8344, issued November 1, 2019, accessed August 7, 2020, https://www.memri.org/reports/ al-jazeeras-midan-voice-internet-channel-jews-created-and-control-porn-industry-order; H. Sharab, “al-Fasad fi al-ard wal-simma al-ta'rikhiyya al-yahudiyya," issued February 24, 2011. 
the corruption of this world and its ruin," or according to Ayatollah Mohammad Taqi Mesbah Yazdi, the grey eminence behind the ultra-conservative faction in Iranian politics "the majority of centers of corruption in the world belong to Jews and Zionists," and added that "the Jews are the most corrupt in the world. You don't find such a tribe in any other nation, country or region."27

The charges of spreading corruption on earth and of being the enemies of God carry with them fateful ramifications. In the Iranian penal system, for example, the indictment of spreading corruption on earth carries with it capital punishment of execution. ${ }^{28}$ In general Islamic parlance it carries divine punishment as stated by the Qur'an to be meted on the Jews as a whole.

The deserving punishment of the Jews according to numerous Islamist spokesmen is annihilation, making modern Islamism the only mass movement after the Holocaust which openly and unequivocally calls for the elimination of an entire people.

According to this perception, the Jews-by insisting on maintaining the State of Israel and by rejecting the idea of living as a protected minority under Islamic rule are in fact waging a war against Islam and against God. Consequently, they have forfeited their right to exist under the historical Pact of 'Umar, and their elimination is their only deserving punishment. Their immoral conduct and criminal activities serve as further justification for their annihilation. Some Islamist spokesmen such as the Jordanian Professor of Islamic Jurisprudence Salah AlKhalidi take comfort that with the establishment of the State of Israel "God brought His filthiest creatures, the Jews" so that the Palestinians can "finish off" the Jews and "rid the world" of them. ${ }^{29}$ Islamist calls during Friday sermons for the elimination of the Jews were so prevalent that in 2002 the Saudi and Kuwaiti governments, possibly to stave off foreign criticism after the September 11 attacks, exerted pressure on preachers to put an end to them. ${ }^{30}$

A prominent demonstration of this genocidal approach from the early 1950s to the present is the justification of the Holocaust as a deserving punishment for

27 S. al-Shawadhfi, al-Yahud nashatan wa-ta'rikhan (Cairo: Dar al-Taqwa, n.d.), 5; http://www. aqsaonline.org/news.aspx?id=4526; MEMRI, Special Dispatch No. 855, issued January 28, 2005; http://www.terrorism-info.org.il/en/article/18156.

28 “On Mofsed fel-Arz-Spreading Corruption on Earth,” Iran Press Watch, May 15, 2009, http:// iranpresswatch.org/post/2737/.

29 MEMRI TV, Clip No. 5260, issued December 29, 2015, accessed August 7, 2020, https://www. memri.org/tv/jordanian-professor-salah-al-khalidi-palestinians-will-rid-world-jews.

30 "Debate regarding the calls over Mosque Pulpits to Exterminate Jews and Christians," MEMRI, issued December 31, 2002, http://www.memri.org.il/cgi-webaxy/sal/sal.pl?lang=he\&ID =875141_memri\&act=show\&dbid=articles\& dataid=1421 [Hebrew; no longer available]. 
the Jews, which is far more prevalent among Islamists than among writers from other political and ideological camps in the Arab world. Thus, Shaykh Muhammad Jami'a, the representative of al-Azhar University, the highest religious institution in the Muslim world in New York during the September 11 terrorist attack, justified Hitler and argued that had the Americans been aware of the extent of Jewish domination in their country, they would have done to the Jews what Hitler had done in his time. ${ }^{31}$

Alongside the justification of the Holocaust, Islamists accuse the Jews of instigating the outbreak of the Second World War as part of the old Jewish trait to foment wars as a means of enriching themselves. Another unique Islamic motif presented Hitler as a victim of Jewish machinations. This line of argument reflected a deep resentment toward "the West" by presenting the US and not Nazi Germany as the state that had committed the worst atrocities in the war. 'Abdallah 'Azzam, a leading ideologue of the radical jihadi-Salafi camp, accused the Jews of declaring an economic war against Hitler and of inciting Britain and France to declare war on Germany under the pretext of defending Poland. Later, the Jews who surrounded President Roosevelt, who had been a Jew too, pushed the US to an imperialist war against Germany. ${ }^{32}$

While most Sunni Islamist movements relegated the messianic elements of Islam to a secondary level, many of them endow eschatological meaning to the elimination of the Jews when they have resorted to the "Promise of the Tree and Stone" tradition (wa'd al-shajar wal-hajr). Accordingly, the Day of Judgment will not come until the Muslims fight the Jews and kill them all. On that day, all the trees and stones would speak and say: "Oh Muslim, oh slave of Allah, there is a Jew behind me. Come and kill him." According to this tradition, the world must be cleansed from Jews before the coming of the Hour. Historically, this tradition did not hold a central place in Islamic literature and was not regarded as very reliable according to Islamic legal procedures. However, with the rise of modern Islamist antisemitism, it was resurrected and given an important place in the Islamist repertoire throughout the region. Thus, some preachers explain the planting of trees in Israel as an indication that Israel acknowledges

31 www.lailatalqadr.com, October 4, 2001 [no longer available]; MEMRI, Special Dispatch No. 288, issued October 19, 2001. For an elaborate analysis of justification of the Holocaust and the difference between Islamists and others, see Litvak and Webman, From Empathy to Denial, $193-214$.

32 'A. 'Azzam, “Tujjar al-hurub,” www.tawhed.ws/a?i=77 [no longer available]. 
the validity of this tradition and prepares the trees for the Jews to hide behind them when the Muslims would come to annihilate them. ${ }^{33}$

The anti-Jewish element has entered the Shi'i eschatological literature as well since the beginning of the twenty-first century, where heretofore it had played an insignificant role. Accordingly, the supposed Jewish animosity against Shi'ism culminates in their efforts to prevent the future apparition (zuhur) of the Twelfth Imam as the Mahdi (Messiah), who will redeem the Shi is. ${ }^{34}$ Consequently, Grand Ayatollah Hossein Nouri-Hamedani concluded that "one should fight the Jews and vanquish them so that the conditions for the advent of the Hidden Imam are met." 35 The Mahdi, according to this new approach, will fight the Jews and defeat them and will severely punish them for their corruption, with some writers predicting that he would annihilate them and "purify the world from the filth of their existence." 36

Finally, the issue of reception of Islamist antisemitism among ordinary Muslims deserves attention. Studies of intellectual history or public discourse in the Middle East face a serious methodological problem of ascertaining reception due to the difficulty of acquiring data on public opinion particularly among the "silent classes." Yet, various indicators do exist. According to Pew research surveys carried out in 2005 and 2011, "anti-Jewish sentiment" is endemic in the Muslim world. ${ }^{37}$ The authors of the 2011 PEW report concluded that "one can-

33 For numerous references of this tradition by Islamist preachers, see "Antisemitic Hadith: 'The Prophecy of The Rock And The Tree'," MEMRI, Special Dispatch No. 7587, issued July 25, 2018, accessed August 7, 2020, https://www.memri.org/reports/antisemitic-hadith-prophecyrock-and-tree-\%E2\%80\%93-memri-clips-and-reports.

34 “Du'ay-e Ayat Allah Qarahi baraye na-budi masihiyat va-yahudiyat,” August 22, 2016, http:// ashnaie.com/6318/; “Khamenei Associate Mehdi Taeb,” MEMRI, Special Dispatch No. 6759. Some writers describe the Zionists as actively working against the Mahdi and seeking to undermine Shi'i belief in him, see R. Zamani Musavi, "Iqdamat va-barnamaha-ye sahyunism dar taqabol amuzeh-ye mahdaviyat dar howzeh-ye farhang," http://www.mahdi313.com/index.php?pg=arti cles\&id $=1634$.

35 A. Nouri-Hamedani, "Fight the Jews and Vanquish Them so as to Hasten the Coming of the 'Hidden Imam'," MEMRI, Special Dispatch No. 897, issued April 22, 2005, accessed August 7, 2020, https://www.memri.org/reports/ayatollah-nouri-hamedani- $\%$ E2\%80\%98fight-jews-andvanquish-them-so-hasten-coming-hidden-imam\%E2\%80\%99.

36 "Nabudi-ye qawm-e yahud dar dowran-e akhar al-zaman," January 13, 2009, http://www. shia-news.com/fa/news/11981; A. 'Ali Kurani, 'Asr al-zuhur (Qom: mu'assasat al-ma'arif al-Islamiyya, 2006), 23-24; A. Reza, Asrar Yahud va-akhar-e zaman (electronic edition, no publisher, 2018), 669.

37 "Support for Terror Wanes Among Muslim Publics," Pew Global Attitudes Project, July 14, 2005, https://www.pewresearch.org/global/2005/07/14/islamic-extremism-common-concern-formuslim-and-western-publics/. 
not understand mass politics in the Arab world without admitting the role of antisemitism." ${ }^{38}$ While the exact figures which these studies bring may be imprecise, the scale of this phenomenon can hardly be disputed.

Islamist antisemitism enjoys wide reception because it draws its themes from the deeply rooted religious tradition of Islam, thereby making it difficult to challenge its claims. The situation of conflict with Israel and continued crisis of Muslim societies ensure its continued popularity because it responds to deep psychological and political needs of large segments of society. It stems from deep conviction and is therefore regarded as more credible and immune from manipulations as might be the case of government-sponsored antisemitism. It occupies a central place in the overall ideology of the Islamist movements, and therefore refuting it requires the challenging of the overall Islamist ideology, and it is disseminated by broad based political and social movements in a wide variety of media. Put differently, Islamist antisemitism is a grassroots phenomenon rather than a state ideology that comes from above, and as such it is likely to remain with us for quite a few years in the future.

Meir Litvak (PhD Harvard 1991) is a Professor at the Department of Middle Eastern History at Tel-Aviv University. Among his books, co-author with Esther Webman, From Empathy to Denial: Arab Responses to the Holocaust (New York: Columbia University Press, 2009). He has edited eight books and published articles on modern Iranian history and on Islamic movements. His book Know Thy Enemy: Attitudes Towards Others in Modern Shii Thought is forthcoming.

\section{References}

Ben-Shammai, Haggai. "Jew-hatred in the Islamic Tradition and the Koranic Exegesis.” In Antisemitism Through the Ages, edited by Shmuel Almog, 161-69. Oxford: Pergamon, 1988.

Buruma, Ian. "The Origins of Occidentalism." The Chronicle of Higher Education. February 6, 2004. https://www.chronicle.com/article/The-Origins-of-Occidentalism/30792.

Cohen, Mark R. Under Crescent and Cross: The Jews in the Middle Ages. Princeton: Princeton University Press, 1994.

Friedmann, Yohanan. Tolerance and Coercion in Islam: Interfaith Relations in the Muslim Tradition. New York: Cambridge University Press, 2003.

38 Cited in E. Webman, “Arab Antisemitic Discourse: Importation, Internalisation, and Recycling," in The Medieval Roots of Antisemitism: Continuities and Discontinuities from the Middle Ages to the Present Day, ed. J. Adams and C. Hess (New York: Routledge, 2018), 161-80. 
Graumann, Carl F., and Serge Moscovici, eds. Changing Conceptions of Conspiracy. London:

Springer, 1987.

Haim, Sylvia G. "Sayyid Qutb." Asian and African Studies 16 (1982): 147-56.

Heschel, Susannah. "Historiography of Antisemitism Versus Anti-Judaism: A Response to

Robert Morgan." Journal for the Study of the New Testament 33, no. 3 (2011): 257-79.

Khumayni, Ruhollah. Al-hukuma al-islamiyya. Beirut: Dar al-Tali'a, 1979.

Khomeini, Ruhollah. Islam and Revolution: Writings and Declarations of Imam Khomeini.

Translated and annotated by Hamid Algar. Berkeley: Mizan, 1981.

Kramer, Martin. "The Jihad Against the Jews." Commentary (October 1994): 38-42.

Kramer, Martin. "The Salience of Islamic Antisemitism." Institute of Jewish Affairs in London "Reports" series 2 (1995).

Langmuir, Gavin I. Toward a Definition of Antisemitism. Berkeley: University of California Press, 1990.

Lewis, Bernard. The Jews of Islam. Princeton: Princeton University Press, 1984.

Lewis, Bernard. "The Roots of Muslim Rage.” The Atlantic Monthly (September 1990): 47-60.

Litvak, Meir. "The Islamization of the Palestinian-Israeli Conflict: The Case of Hamas." Middle Eastern Studies 34, no. 1 (1988): 148-63.

Litvak, Meir, and Esther Webman. From Empathy to Denial: Arab Responses to the Holocaust. New York: Columbia University Press, 2009.

Tadros, Samuel. "The Sources of Egyptian Anti-Semitism.” American Interest, April 21, 2014. https://www.the-american-interest.com/2014/04/21/the-sources-of-egyptian-anti-semi tism/.

Tibi, Bassam. The Challenge of Fundamentalism: Political Islam and the New World Disorder. Berkeley: University of California Press, 2002.

Vajda, Georges. “Juifs et musulmans selon le hadith.” Journal Asiatique 229 (1937): 57-127.

Wasserstrom, Steven. Between Muslim and Jew: The Problem of Symbiosis under Early Islam. Princeton: Princeton University Press, 2014.

Webman, Esther. "Arab Antisemitic Discourse: Importation, Internalisation, and Recycling." In The Medieval Roots of Antisemitism: Continuities and Discontinuities from the Middle Ages to the Present Day, edited by Jonathan Adams and Cordelia Hess, 161-80. New York: Routledge, 2018.

Webman, Esther. "The Challenge of Assessing Arab/Islamic Antisemitism." Middle Eastern Studies 46, no. 5 (2010): 677-97.

Webman, Esther. "The 'Jew' as a Metaphor for Evil in Arab Public Discourse.” The Journal of the Middle East and Africa 6, nos. 3-4 (2015): 275-92.

Ye'or, Bat. The Dhimmi: Jews and Christians under Islam. Rutherford: Fairleigh Dickinson University Press, 1996.

Zeidan, David. "The Islamic Fundamentalist View of Life as a Perennial Battle.” Middle East Review of International Affairs 5, no. 4 (2001). https://myislam.dk/articles/en/zeidan\% 20the-islamic-fundamentalist-view-of-life-as-a-perennial-battle.php.

Zukier, Henri. "The Conspiratorial Imperative: Medieval Jewry in Western Europe." In Changing Conceptions of Conspiracy, edited by C. F. Graumann and S. Moscovici, 87-105. London: Springer, 1987. 